\title{
Motivasi Petani dalam Membudidayakan Tanaman Pepaya Calina (Carica papaya L) (Kasus Kelompok Tani Pepaya Calina di Desa Sulangai, Kecamatan Petang, Kabupaten Badung)
}

\author{
DEWA PUTU GEDE SATRIA WIWEKA, I DEWA PUTU OKA SUARDI, A.A.A \\ WULANDIRA SDJ
}

Program Studi Agribisnis, Fakultas Pertanian, Universitas Udayana Jl. PB. Sudirman 80232 Bali

Email:dewa.wiweka@yahoo.com

okasuardi@unud.ac.id

\author{
Abstract \\ The Farmer's Motivation In Cultivating The Papaya Calina Plant \\ (Carica papaya L) (The Farmer's Group of Calina Papaya at Sulangai Village, on \\ Petang District, in Badung Regency).
}

Sulangai village is the village where most of the villagers work as a farmer. One of the farmer's work done by the farmer in that village is papaya calina. Based on the description above, it's interesting to analyze about the motivation faced by the farmer in cultivating the papaya calina plant at Sulangai village, on Petang district, in Badung regency. The purpose of this research is to know the farmer's motivation in cultivating the papaya calina plant at Sulangai village, on Petang district, in Badung regency. The research held at sulangai village, on Petang district, in Badung regency particularly in farmer's group of papaya calina. The location of the research is based on the purposive method which is determination of the research location deliberately. The population in this research is 20 farmers.

Based on the research data, the intrinsic motivation of the farmer cultivating the papaya calina plant at Sulangai village, on Petang district, in Badung regency is categories high percentage about $70,81 \%$. The intrinsic motivation of the farmer in cultivating the papaya calina plant generally categories in high percentage about 79,09\%. Based on the research the farmer's group as the one who does this job is brave to try this technology in cultivating the papaya calina plant which is given by the instructor. By trying the technology, the farmer's group will get more new experiences to do in cultivating papaya calina in the future.

Key words : motivation, farmer's group, cultivate. 


\section{Pendahuluan}

\subsection{Latar Belakang}

Pembangunan sektor pertanian di Bali masih menjadi prioritas dalam pembangunan daerah. Pembangunan pertanian dilakukan untuk menunjang pertumbuhan dan stabilitas ekonomi, terutama dalam meningkatkan pendapatan sebagian besar masyarakat dalam produksi dan nilai tambah, serta dapat mendorong laju pertumbuhan ekonomi di desa tertinggal. Sektor pertanian di Bali masih mampu memberi kontribusi yang besar dalam hal penyerapan tenaga kerja.

Pembangunan pertanian di Bali terancam oleh tingginya angka konversi lahan pertanian.Pertanian yang masih terfokus pada budidaya tanaman padi membuat harga gabah pada waktu panen raya menjadi rendah, hal ini tidak sebanding dengan biaya produksi yang terus mengalami peningkatan. Tingkat konversi lahan juga dipengaruhi oleh kondisi petani di Bali yang umumnya sebagai petani marginal, yang hanya memiliki lahan, peralatan, modal, daya kerja, dan kemampuan mengelola yang sangat terbatas untuk dapat mengolah usaha pertanian yang menghasilkan keuntungan (Sujipta dan Windia, 1990).

Desa Sulangai yang berada di Kecamatan Petang, Kabupaten Badung, merupakan Desa yang sebagai besar penduduknya bermata pencaharian di bidang pertanian. Salah satu usahatani yang ada di Desa Sulangai adalah pepaya calina. Desa Sulangai memiliki struktur tanah yang subur, sehingga sangat cocok untuk ditanami pohon pepaya calina. Kelompok tani pepaya calina terbentuk pada tahun 2013 dengan jumlah anggota kelompok tani saat ini sekitar 20 orang dengan memiliki lahan kurang lebih 9,65 ha,dalam membudidayakan tanaman ini anggota kelompok tani ini di dampingi oleh PPL.Pepaya calina sengaja dibudidayakan karena merupakan salah satu varietas pepaya yang saat ini sangat diminati oleh masyarakat.

Meskipun demikian di dalam melakukan budidaya mengalami kendala berupa ketahanan buah akan cepat rusak bila musim hujan telah tiba, di mana buah pepaya calina akan mengalami berbagai serangan penyakit seperti jamur, busuk akar, plak berbintik kecoklatan pada daun, serta rasa akan sedikit berkurang.

Berdasarkan uraian tersebut, maka menarik untuk dikaji mengenai tingkat motivasi yang di hadapi petani dalam membudidayakan tanaman pepaya calina di Desa Sulangai, Kecamatan Petang, Kabupaten Badung.

\subsection{Rumusan Masalah}

Berdasarkan uraian latar belakang di atas, maka dapat dirumuskan "Bagaimanakah motivasi petani dalam membudidayakan tanaman pepaya calina di Desa Sulangai, Kecamatan Petang, Kabupaten Badung”. 


\subsection{Tujuan Penelitian}

Adapun tujuan dari penelitian ini yaitu untuk mengetahui motivasi petani dalam membudidayakan tanaman pepaya calina di Desa Sulangai, Kecamatan Petang, Kabupaten Badung.

\section{Metode Penelitian}

\subsection{Lokasi dan Waktu Penelitian}

Penelitian ini dilakukan di Desa Sulangai, kecamatan Petang, Kabupaten Badung khususnya di kelompok tani pepaya calina pada bulan maret 2015 sampai Januari 2017.

\subsection{Teknik Pengumpulan Data, Instrumen Pengumpulan Data, Variabel Penelitian, dan Metode Analisis}

Metode pengumpulan data yang digunakan dengan teknik wawancara dan observasi.Instrumen pengumpulan data yang digunakan adalah dengan cara memberi seperangkat pertanyaan atau pernyataan tertulis kepada responden untuk dijawab yang disebut kuesioner (Sugiyono, 2008). Variabel adalah atribut suatu objek yang mempunyai nilai yang bervariasi, yang dipelajari oleh peneliti dan ditarik kesimpulannya (Antara dalam Roman, 2013).Variabel pada penelitian ini adalah motivasi intrinsik dan motivasi ekstrinsik.Metode analisis yang digunakan adalah analisis deskriptif kualitatif.

\subsection{Penentuan Populasi dan Sampel}

Populasi adalah sekelompok objek atau individu atau peristiwa yang menjadi perhatian peneliti, yang dikenai generalisasi penelitian (Gay dalam Roman, 2013).Populasi dalam penelitian ini adalah seluruh anggota Kelompok tani pepaya calina yang membudidayakan pepaya calina di Desa Sulangai, Kecamatan Petang, Kabupaten Badung yang berjumlah 20 orang petani.

Dikemukakan oleh (Sevilla, 1993) sampel adalah kelompok kecil yang diamati dalam penelitian.Responden didefinisikan sebagai himpunan nilai/skor yang tercatat atau diobservasi berkaitan dengan peristiwa atau fakta yang telah terjadi.

Sampel ditentukan dengan metode sensus.Metode sensus adalah metode yang keseluruhan anggota populasi dijadikan responden (Sugiyono, 1994 dalam Sasetyowati, 2013). Sampel dari obyek penelitian ini adalah seluruh anggota dari kelompok tani pepaya calina yang berjumlah 20 orang.

\section{Hasil dan Pembahasan}

\subsection{Karakteristik Responden}

Beberapa karakteristik responden yang dibahas meliputi jenis kelamin, umur, tingkat pendidikan formal, pekerjaan, kepemilikan, dan penguasaan lahandan jumlah anggota rumah tangga. 


\subsubsection{Jenis kelamin}

Hasil penelitian menunjukkan bahwa semua responden berjenis kelamin laki-laki. Hal tersebut dipengaruhi oleh status mereka adalah sebagai kepala rumah tangga. Tidak adanya responden perempuan dipengaruhi kebiasaan masyarakat di Desa tersebut, bahwa laki-laki yang paling bertanggung jawab untuk menjadi kepala rumah tangga, sehingga secara keseluruhan responden pada penelitian ini berjenis kelamin laki-laki.

\subsubsection{Umur responden}

Dikemukakan oleh Elisabeth B.H (1997), usia adalah umur yang diukur dengan tahun dan lamanya hidup dalam hidup dihitung sejak dilahirkan. Pendapat lain, dinyatakan oleh Dewi dan Wawan (2010) semakin cukup umur, tingkat kematangan, dan kekuatan seseorang akan lebih matang dalam berpikir dan bekerja(Darmada, 2011). Penggolongan umur di bawah 15 tahun dan di atas 64 tahun dikelompokkan ke dalam umur non produktif. Hasil penelitian menunjukkan bahwa umur responden lebih banyak berada pada usia produktif dengan rata-rata umur responden 48,35 tahun yang termasuk dalam kategori produktif. Hal ini berarti bahwa responden menerima pengetahuan dan informasi baru untuk memperbaiki usahataninya.

\subsubsection{Tingkat pendidikan responden}

Pendidikan merupakan salah satu faktor yang mendorong kemampuan seseorang untuk menyerap teknologi dan ilmu pengetahuan. Tingkat pendidikan yang memadai membuat petani akan semakin mengerti dan memahami materi-materi yang disampaikan atau diberikan oleh penyuluh serta mempengaruhi kemampuan petani untuk menerima dan mencoba inovasi baru (Thoha, 2004).

Hasil penelitian menunjukkantingkat pendidikan formal responden Kelompok Tani pepaya calina cukup merata. Hal ini dapat dilihat dari tamatan SMP sampai perguruan tinggi yang dikenyam responden lebih banyak, yaitu sebanyak 16 orang $(80,00 \%)$ dari pada responden yang mengenyam pendidikan sekolah dasar dan tidak tamat SD yang hanya berjumlah 4 orang $(20,00 \%)$. Hal ini berarti responden di kelompok tani pepaya calina memiliki kemampuan yang baik dalam menerima suatu pengetahuan baru, sehingga menyebabkan terjadinya perilaku menerima dari beberapa petani terhadap inovasi baru yang diberikan oleh penyuluh dan lebih cenderung mau mencoba sistem baru yang mereka ketahui, dengan menerapkan inovasi yang mereka dapat dari penyuluh.

\subsubsection{Mata pencaharian}

Hasil penelitian menyatakan bahwa mata pencaharian pokok terbanyak responden sebagai petani sebanyak 9 orang $(45,00 \%)$, dan 11 orang lainnya $(55,00 \%)$ memiliki pekerjaan pokok sebagai PNS, pekerja bangunan, wiraswasta dan pedagang. Pekerjaan pokok sebagai PNS dan pekerja bangunan yang dijalankan responden semata-mata karena memiliki lahan untuk melakukan kegiatan usahatani guna mendapatkan penghasilan tambahan, sedangkan responden yang tidak memiliki pekerjaan sampingan 
mempunyai alasan bahwa mereka menjadi petani sudah cukup untuk memenuhi kebutuhan keluarga.

\subsubsection{Jumlah anggota rumah tangga}

Hasil penelitian menunjukkan bahwamayoritas responden memiliki jumlah anggota rumah tangga yang terdiri atas empat orang sampai lima orang,(keluarga inti), sebanyak 17 responden (86,36\%). Artinya semakin banyak anggota rumah tangga yang ada akan mempengaruhi motivasi mereka dalam bekerja untuk mendapatkan penghasilan yang bisa mencukupi seluruh anggota rumah tangganya.

\subsection{Motivasi Petani dalam Membudidayakan Tanaman Pepaya Calina (carica papaya $L$ )}

Tingkat motivasi seseorang dapat dipengaruhi oleh sumber motivasi. Sumber motivasi dapat dibagi menjadi dua macam, yakni motivasi intrinsik dan motivasi ekstrinsik. Motivasi intrinsik merupakan dorongan belajar pada diri seseorang yang berasal dari kesadaran sendiri akan kebutuhan belajar tersebut, sedangkan motivasi ekstrinsik merupakan motivasi atau dorongan yang timbul dari luar atau orang lain Wanardi (2002).

Berdasarkan data hasil penelitian, tingkat motivasi petani dalam membudidayakan tanaman pepaya calina di Desa Sulangai, Kecamatan Petang, Kabupaten Badung termasuk kategori tinggi, dengan pencapaian skor sebesar 3,74. Skor ini didapat melalui penjumlahan skormotivasi intrinsik dan motivasi ekstrensik.

Tingkat motivasi yang termasuk kategori tinggi menunjukkan bahwa, petani melakukan budidaya tanaman pepaya calina karena mendapat dorongan yang besar baik dalam dirinya maupun dari orang lain. Jika dilihat dari motivasi instrinsik, tingkat motivasi yang menandakan petani ingin meningkatkan kemampuannya untuk dapat menanam pepaya calina dengan baik, karena kemampuan yang baik dalam membudidayakan pepaya calina bisa meningkatkan kualitas buah yang baik dan dapat meningkatkan hasil panen buah pepaya calina agar dapat menambah penghasilan yang mereka dapatkan.

Apabila dilihat dari motivasi ekstrinsik menunjukkan adanya dorongan yang besar dari luar petani (orang lain) untuk membudidayakan tanaman pepaya calina. Dorongan tersebut dapat berasal dari kelompok tani, PPL, petani lain, pedagang/pengepul, dan konsumen. Motivasi yang diberikan dapat berupa dorongan, tarikan, pelibatan atau pengikutsertaan, dan rangsangan, sehingga petani yang sebelumnya menanam komoditi tertentu kemudian beralih membudidayakan tanaman pepaya calina untuk meningkatkan pendapatan rumah tangga petani. Secara terperinci hasil persentase mengenai tingkat motivasi petani dalam membudidayakan tanaman pepaya calina di Desa Sulangai, Kecamatan Petang, Kabupaten Badung dapat dilihat pada tabel 1 
Tabel 1.

Tingkat Motivasi Petani dalam Membudidayakan Tanaman pepaya calina pada Kelompok Tani pepaya calina di Desa Sulangai, Kecamatan Petang, Kabupaten

Badung 2016

\begin{tabular}{cccc}
\hline No & $\begin{array}{c}\text { Variabel Sumber } \\
\text { Motivasi }\end{array}$ & Pencapaian Skor & Kategori \\
\hline 1 & Motivasi Intrinsik & 3,54 & Tinggi \\
2 & Motivasi Ekstrinsik & 3,95 & Tinggi \\
\hline & Tingkat Motivasi & 3,74 & Tinggi \\
\hline
\end{tabular}

\subsubsection{Motivasi intrinsik}

Hasil dari penelitian menunjukkan tingkat motivasi intrinsik petani dalam membudidayakan tanaman pepaya calina di Desa Sulangai, Kecamatan Petang, Kabupaten Badung termasuk kategori tinggi dengan pencapaian skor 3,54. Tingginya motivasi intrinsik petani dalam membudidayakan tanaman pepaya calina menunjukkan adanya kebutuhan hidup petani yang belum terpenuhi atau petani belum puas dengan pemenuhan kebutuhan hidup mereka saat ini, sehingga petani melakukan budidaya tanaman pepaya calina untuk memenuhi kebutuhan anggota rumah tangga petani.

Tingginya motivasi intrinsik petani akan membuat tingkat keberhasilan petani dalam melakukan budidaya tanaman pepaya calina juga tinggi, karena petani melakukan budidaya bukan karena paksaan dari pihak lain. Motivasi intrinsik petani yang tertinggi berasal dari parameter kebutuhan pokok, termasuk kategori sangat tinggi dengan pencapaian skor 4,37. Ini menunjukkan bahwa petani membudidayakan tanaman pepaya calina untuk menambah pendapatan agar dapat memenuhi kebutuhan rumah tangga. Petani menganggap budidaya tanaman pepaya calina menguntungkan secara finansial maupun non finansial. Secara finansial penghasilan petani bertambah dari hasil penjualan buah pepaya calina, sedangkan secara non finansial dapat memanfaatkan lahan yang dulunya kurang produktif menjadi lahan produktif setelah dijadikan lahan budidaya tanaman pepaya calina sehingga dapat dijadikan bisnis menguntungkan serta mampu menambah pendapatan petani.

Berbeda dengan kebutuhan pokok petani, pencapaian skor pada parameter kebutuhan akan rasa aman petani dalam membudidayakan tanaman pepaya calina termasuk kategori sedang, dengan pencapaian skor 2,81. Artinya petani sudah cukup puas dengan pemenuhan kebutuhan akan rasa aman saat melakukan budidaya tanaman pepaya calina, sehingga pemenuhan kebutuhan ini tidak menjadi prioritas saat ini. Kebutuhan ini dipenuhi melalui kemampuan petani dalam meminimalisir hal-hal yang dapat mengancam keberhasilan budidaya tanaman pepaya calina yang mereka lakukan. Kebutuhan akan rasa aman yang dimaksud petani ialah kecilnya resiko kecelakaan fisik, resiko gagal panen akibat pengaruh cuaca dan serangan hama penyakit, serta resiko pencurian dalam melakukan budidaya tanaman pepaya calina.

Parameter yang paling rendah yaitu pada parameter kebutuhan akan penghargaan dengan skor 2,10 artinya petani belum cukup puas atas kebutuhan akan penghargaan, 
meskipun pemerintah memberi bantuan berupa biji buah pepaya calina, petani merasa bantuan tersebut belum cukup untuk mengembangkan usahatani mereka.

Parameter kebutuhan sosial mencapai skor 4,12 termasuk kategori tinggi. Ini menjelaskan bahwa petani melakukan budidaya tanaman pepaya calina karena ada kebutuhan sosial yang dapat terpenuhi. Kebutuhan sosial yang dimaksud yaitu adanya komunikasi yang baik antar petani pepaya calina karena membudidayakan tanaman yang sama. Petani juga menjalin hubungan kerja yang harmonis dan kompak baik saat menggunakan tenaga kerja dalam keluarga maupun saat menggunakan tenaga kerja diluar keluarga.

Parameter kebutuhan aktualisasi diri mencapai skor 4,30. Data ini menunjukkan kategori sangat tinggi. Ini menunjukkan membudidayakan tanaman pepaya calina merupakan keinginan petani untuk mengembangkan usahanya yang sangat besar, karena buah pepaya calina merupakan varietas buah pepaya unggul. Secara terperinci tingkat motivasi intrinsik petani dalam membudidayakan tanaman pepaya calina dapat dilihat pada tabel 2.

Tabel 2.

Tingkat Motivasi Intrinsik Petani dalam Membudidayakan

Tanaman Pepaya Calina pada Kelompok Tani Pepaya Calina di Desa Sulangai, Kecamatan Petang, Kabupaten Badung, Tahun 2016.

\begin{tabular}{llcl}
\hline No & \multicolumn{1}{c}{$\begin{array}{c}\text { Indikator Motivasi } \\
\text { Intrinsik }\end{array}$} & Pencapaian Skor & Kategori \\
\hline 1 & Kebutuhan pokok & 4,37 & Sangat tinggi \\
2 & Kebutuhan sosial & 4,12 & Tinggi \\
3 & Kebutuhan akan rasa aman & 2,81 & Sedang \\
4 & Kebutuhan akan & 2,10 & Rendah \\
& penghargaan & & \\
5 & Kebutuhan aktualisasi diri & 4,30 & Sangat tinggi \\
\hline Tingkat motivasi intrinsik & 3,54 & Tinggi \\
\hline
\end{tabular}

\subsubsection{Motivasi ekstrinsik}

Hasil dari penelitian menunjukkan tingkat motivasi ekstrinsik petani dalam membudidayakan tanaman pepaya calina secara keseluruhan termasuk kategori tinggi dengan pencapaian skor 3,95. Data ini menunjukkan bahwa selain mendapat dorongan dari dalam dirinya, budidaya tanaman pepaya calina yang dilakukan petani juga dikarenakan dorongan dari luar (orang lain). Tingginya motivasi ekstrinsik yang dimiliki petani akan berpengaruh terhadap keberhasilan petani dalam melakukan budidaya tanaman pepaya calina, karena ada faktor-faktor pendukung atau pendorong dari luar diri petani. Motivasi ekstrinsik petani berasal dari kelompok tani, PPL, petani lain, pedagang/pengepul, dan konsumen.

Motivasi ekstrinsik petani yang terbesar berasal dari konsumen yang termasuk kategori sangat tinggi. Motivasi dari konsumen mencapai skor 4,32. Artinya pepaya calina sangat diminati masyarakat karena harga pepaya calina sangat terjangkau oleh 
masyarakat luas, manfaat buah sangat baik untuk kesehatan, serta buah pepaya calina mampu bertahan lebih dari satu minggu.

Pencapaian skor dari motivasi pedagang/pengepul yang termasuk kategori sangat tinggi mencapai skor 4,25. Hal ini menunjukkan petani melakukan budidaya tanaman pepaya calina karena ada rangsangan dari pedagang/pengepul. Rangsangan ini berupa ajakan atau bujukan dari pedagang/pengepul berupa hasil panen yang akan selalu di beli. Selain itu, pedagang/pengepul tidak memonopoli harga pepaya calina dari petani, serta kesediaan pedagang/pengepul memberikan pinjaman bagi petani dan dapat dibayar dengan memotong hasil penjualan pepaya calina sehingga petani akan terus melakukan budidaya tanaman pepaya calina.

Pada parameter kelompok tani mencapai skor 4,25 yang termasuk kategori sangat tinggi. Artinya adanya dorongan besar dari kelompok tani yang mampu menggerakan petani untuk melakukan budidaya tanaman pepaya calina.

Motivasi dari PPL mencapai skor 4,20 yang mencapai kategori sangat tinggi. Hasil ini menunjukkan bahwa dorongan yang diberikan PPL sangat besar bagi petani, dimana PPL memberikan pelatihan maupun pendidikan mengenai teknik budidaya tanaman pepaya calina, apalagi pendidikan rata-rata responden mencapai tamatan SLTA sebanyak 10 orang $(50,00 \%)$, ini menyebabkan petani relatif lebih mudah untuk menerima suatu ilmu pengetahuan dibandingkan dengan orang-orang yang tingkat pendidikannya rendah.

Hasil yang berbeda ditunjukkan pencapaian skor motivasi ekstrinsik dari petani lain, yakni hanya sebesar 2,83 yang termasuk kategori sedang. Artinya tidak adanya dorongan yang terlalu besar dari petani lain yang mampu menggerakkan petani untuk melakukan budidaya tanaman pepaya calina, sedangkan untuk komunikasi dalam melakukan budidaya tanaman pepaya calina termasuk kategori tinggi. Komunikasi yang dimaksud yakni keterbukaan setiap petani mengenai teknik budidaya yang mereka lakukan, pertukaran informasi mengenai tempat pembelian bibit tanaman pepaya calina serta obat-obatan. Secara terperinci tingkat motivasi ekstrinsik petani dalam membudidayakan tanaman pepaya calina dapat dilihat pada tabel 3.

\section{Tabel 3.}

Tingkat Motivasi Ektrinsik Petani dalam membudidayakan

Tanaman Pepaya Calina pada Kelompok Tani Pepaya Calina di Desa Sulangai, Kecamatan Petang, Kabupaten Badung, Tahun 2016.

\begin{tabular}{llcl}
\hline No & \multicolumn{1}{c}{$\begin{array}{c}\text { Indikator Motivasi } \\
\text { Ekstrinsik }\end{array}$} & Pencapaian Skor & \multicolumn{1}{c}{ Kategori } \\
\hline 1 & Kelompok Tani & 4,25 & Sangat Tinggi \\
2 & PPL & 4,20 & Sangat Tinggi \\
3 & Petani Lain & 2,83 & Sedang \\
4 & Pedagang/pengepul & 4,25 & Sangat Tinggi \\
5 & Konsumen & 4,32 & Sangat Tinggi \\
\hline Tingkat Motivasi Ekstrinsik & 3,95 & Tinggi \\
\hline
\end{tabular}




\section{Simpulan dan saran}

\subsection{Simpulan}

Berdasarkan hasil penelitian dan pembahasan dapat disimpulkan bahwa motivasi petani dalam membudidayakan tanaman pepaya calina termasuk kategori tinggi, dimana motivasi intrinsik dan motivasi ekstrinsik sama-sama termasuk kategori tinggi.

\subsection{Saran}

Dari hasil dan pembahasan yang sudah dijabarkan, maka saran yang dapat diberikan bagi petani pepaya calina adalah dengan mengintensifkan pengendalian hama dan penyakit pada saat musim hujan tiba, banyak masalah pada serangan hama penyakit pada tanaman pepaya calina mereka. Oleh karena itu sebaiknya dari pihak PPL melakukan koordinasi dengan ahli terkait yang tentunya dibantu oleh pemerintah guna penanggulangan hama dan penyakit yang masih sering menyerang tanaman pepaya petani guna meningkatkan hasil panen serta kesejahteraan dari kelompok tani pepaya calina.

\section{Ucapan Terima Kasih}

Puji syukur penulis panjatkan kehadapan Ida Sang Hyang Widhi Wasa atau Tuhan Yang Maha Esa karena atas rahmat-Nya penelitian ini dapat diselesaikan. Penulis menyampaikan terima kasih kepada semua pihak yang telah membantu dan memberikan dukungan baik secara moril maupun materiil dalam proses penyelesaian penelitian ini hingga termuat di e-jurnal.

\section{Daftar Pustaka}

Darmada, Ida Bagus Kade Dwi. 2011. Partisipasi masyarakat dalam Upaya Pelestarian Mangrove Tanaman Hutan Raya Ngurah Rai.Skripsi tidak dipublikasikan. Program Studi Agribisnis, Fakultas Pertanian, Universitas Udayana denpasar.

Dewi dan Wawan. 2010. Teori dan Pengukuran Pengetahuan, Sikap, dan Perilaku Manusia. Nuha Medika. Yogyakarta

Elisabeth, B.H. 1997. Psikologi Perkembangan Suatu Pendekatan Sepanjang Rentang Kehidupan. Erlangga Jakarta.

Roman, Umbu. 2013. Kendala Dan Upaya Dalam Peningkatan Produksi Padi (Studi Kasus di Subak Pedahanan, Desa Angentaka, Kecamatan Abiansemal, Kabupaten Badung). Skripsi. Denpasar: Program Studi Agribisnis. Fakultas Pertanian. Universitas Udayana.Sugiyono. 2011. Pengertian Kuesioner. Internet.http://widisudharta.weebly.com/metode-penelitian-skripsi.html. Diakses pada 5 November 2014.

Sevilla. 1993. Pengantar Metode Penelitian.Universitas Indonesia. Jakarta.

Sasetyowati, Tyas. 2013. Metodologi Penelitian. Skripsi.Universitas Pendidikan Indonesia.

Sugiyono. 2008.2 Pengertian Kuesioner. Internet.http://widisudharta.weebly.com/metode-penelitian-skripsi.html. Diakses pada 21 Maret 2015. 
Sujipta dan Windia.1990. Profil Pertanian di Daerah Bali. Denpasar: Fakultas Pertanian Universitas Udayana.

Thoha. 2004. Faktor yang Mempengaruhi Perkembangan Persepsi Seseorang. [Jurnal Online]. http://balittanah.litbang.deptan.go.id.Diunduh Tanggal 25 Mei 2016

Wanardi,J. 2002. Motivasi dan Pemotivasian dalam Manajemen. PT. Raja Grafindo Persada Jakarta. 